\title{
Designing Authentic Learning Activities in Islamic Higher Education: A Conceptual Paper
}

\author{
Fadlil Yani Ainusyamsi \\ Universitas Islam Negeri (UIN) Sunan Gunung Djati, Bandung \\ Email: fy.ainusyamsi@gmail.com \\ Received: January 20, 2020 | Accepted: June 15, 2020
}

\begin{abstract}
Conceptually, authentic learning is believed to be able to improve the quality of education and learning in higher education. Through authentic learning, students are invited to recognize everyday experiences and then are constructed into meaningful knowledge. Authentic learning also offers learning traditions that are not always based on text. This research offers an authentic learning design in Islamic tertiary institutions. Through a search of current and credible research reports, this article has succeeded in developing authentic learning designs in Islamic tertiary institutions.
\end{abstract}

\begin{abstract}
Abstrak
Secara konseptual, pembelajaran otentik dipercaya mampu meningkatkan mutu pendidikan dan pembelajaran di perguruan tinggi. Melalui pembelajaran otentik, mahasiswa diajak untuk mengenali pengalaman sehari-hari kemudian dikonstruksi menjadi pengetahuan bermakna. Pembelajaran otentik juga menawarkan tradisi belajar yang tidak melulu bersumber pada teks. Penelitian ini menawarkan perancangan pembelajaran otentik di perguruan tinggi Islam. Melalui penelusuran terhadap laporan-laporan penelitian terkini dan kredibel, artikel ini berhasil mengembangkan rancangan pembelajaran otentik di perguruan tinggi Islam.
\end{abstract}

\section{Keywords}

Authentic learning, Islamic education, Islamic higher education

\section{Introduction}

The quality of learning in Islamic higher education institutions is not optimal. Several factors cause the quality of learning is not optimal. Several 
factors that cause the quality of learning are still low include academic atmosphere, educational facilities, and infrastructure, lecturer competencies, model selection, learning strategies and methods, classroom design, interests and motivation of lecturers and students, lecturer welfare (Husni, 2016). Besides, learning in Islamic higher education institutions is too much based on textbooks. Empirical facts are almost absent during the learning process. Studying at this institution is synonymous with reading, understanding, and studying textbooks. Worse yet, the textbooks which are the source of learning are classic textbooks, which were published tens or even hundreds of years ago (Husni, 2019a).

In this study, researchers assume that the choice of learning models is an essential variable in realizing quality learning. The right learning model, which is appropriate to the characteristics of students, will help students to achieve learning goals. In addition to being following the characteristics of students, learning models also need to be adapted to the characteristics of subjects and the environment of educational institutions. That is why choosing the right learning model will determine whether or not a quality process and learning outcomes.

In the practice of learning in Islamic higher education institutions, the quality of learning is determined by some factors, both factors originating from lecturers, students, facilities, tools and learning media, and environmental factors of Islamic higher education institutions. The quality of learning in Islamic higher education institutions is believed to be influenced by factors originating from lecturers because lecturers are a very crucial component in the implementation of a learning model. Without lecturers, however excellent and ideally a learning model, then the learning model might not be optimally applied. Successful implementation of a learning model will depend on the competence of lecturers in using learning models, methods, techniques, and tactics. It is believed, each lecturer will have different experiences, knowledge, abilities, styles, and even views in teaching. Lecturers who think education is only limited to delivering subject matter will be different from lecturers who think education is a process of assisting students. Each of these differences can affect both in the preparation of learning models and the implementation of learning.

In the learning process, lecturers play a vital role. The role of lecturers cannot possibly be replaced by other devices, such as television, radio, computers, and so on, because students are developing organisms that need guidance and assistance from adults. In the learning process, the lecturer not only acts as a model or role model for the students he teaches but also as a manager of learning. 
In the learning process, the lecturer factor influences several aspects of education, ranging from teacher formative experience (experiences related to the development of lecturers), teacher training experience (training experiences participated by lecturers), and teacher properties (lecturer properties). Formative experience teacher includes gender and all life experiences of lecturers who become their social background. Involved in this aspect include cultural history and customs, the family situation of the lecturer comes from, for example, whether the lecturer comes from a family that is classified as capable or not, whether they come from a harmonious family or not. Teacher training experience includes experiences related to the activities and educational backgrounds of lecturers, for example, professional training experience, level of education, job experience, and so on. Teacher properties are everything related to the nature of lecturers, for example, lecturers' attitudes toward their profession, lecturers' attitudes toward students, lecturers' abilities or intelligence, their motivation and abilities, both their ability to manage to learn, including their ability to plan and evaluate learning and capacity in mastering subject matter.

However, the ability of lecturers to master the right learning model becomes very important in supporting the success of the learning process. The strength of lecturers to apply appropriate learning models, thus, is also very important to realize quality learning processes and outcomes. This conceptual research aims to elaborate on authentic learning models in learning activities in Islamic higher education institutions. Also, this study seeks to offer theoretical steps in carrying out authentic learning in Islamic higher education institutions.

\section{Methods}

This study is conceptual research. The method of study is a literature review based. Critical analysis is used to read, understand, and analyze data from much relevant literature. The researchers also reflected on the researchers' own knowledge and experience while becoming an education practitioner within an Islamic higher education institution. Researchers conducted a study of several primary works of literature on authentic learning models. The researchers conducted intense discussions to offer authentic learning models in the environment of Islamic higher education institutions. Thus, the data was also obtained through mutual reflection among researchers. 


\section{Results and Discussion}

\section{The nature of authentic learning}

An authentic learning method is defined as methods that require students to produce (not only reproduce) knowledge relevant to their lives through careful investigation and to achieve ways that are useful for themselves and the community (Duis, 1995; Mishan, 2005). Authentic learning is a pedagogical approach that allows students to explore, discuss, and build meaningful concepts and relationships in contexts involving real-world problems and projects that are relevant to students (Donovan, Bransford, \& Pellegrino, 1999). Authentic learning is a pedagogical approach that places learning assignments in the context of future use (J. Herrington, Reeves, \& Oliver, 2014). Authentic learning is a measure of relevance or compatibility of the curriculum with the world that students will enter after graduation (McKenzie, Morgan, Cochrane, Watson, \& Roberts, 2002).

In the perspective of constructivist learning, learning must be relevant, realistic, authentic, and represent the natural complexity of the 'real world'. Proponents of constructivist learning advocate the close alignment between constructivism as an educational philosophy and authentic learning as a pedagogical ideal (Jonassen, 1991, 1994; McKenzie et al., 2002; Wilson \& Cole, 1991). Authentic learning means learning to use real-world problems and activities that allow students to explore and discuss these problems in ways that are relevant to them (Cooper, 2011; Schumacher \& Reiners, 2013).

Authentic learning is a model for robust education based on research on learning and cognition (Mishan, 2005). The theory of constructivism postulates that the best way students learn is by engaging in authentic learning tasks, by asking questions, and by drawing on past experiences (J. Herrington, 2010). In short, for learning to happen for students, it must be done in a way and in a place that is relevant to their real-life, both inside and outside the classroom (A. Herrington \& Herrington, 2006; J. Herrington, 2010; J. Herrington \& Parker, 2013; J. Herrington et al., 2014).

Authentic learning model (authentic learning) is a learning model that allows students to explore, discuss, and build meaningfully concepts and relationships, involving real problems and activities that are relevant to students (Parisi \& Crosby, 2012). The term 'authentic' means original, genuine, and real (Agostinho, 2006).

Authentic learning activities focus on the real world, complex problems, and solutions (Robertson, 2014). An authentic activity learning environment provides a "real world" application or discipline (Robertson, 2014). Authentic learning usually focuses on the real world, complex problems, and their 
solutions, using role-playing exercises or role-playing, problem-based learning, case studies, and participation in virtual practice communities (Hillis, 2008; Slepkov, 2008). The learning environment is made inherently multidisciplinary. The learning environment is not built to teach subjects in the abstract (Banas, 2014; Murphy, 2006). Authentic learning environments provide "real-world" applications, such as doing good, building places of worship, giving alms, solving unlawful actions, etc. taught with multidisciplinary, multi-perspective games, alternative ways of working, thinking habits, and conditions of students at Public. Students need to cultivate "portable abilities" or abilities that can be carried as a basis in authentic learning activities. These portable capabilities include (1) assessments to distinguish reliable and unreliable information; (2) patience to follow various arguments; (3) the ability of synthesis to recognize relevant patterns in a foreign context; and (4) flexibility to work across disciplinary and cultural boundaries to produce innovative solutions (Andersson \& Andersson, 2005).

Authentic learning is very different from traditional learning methods. The characteristics of authentic learning are (1) learning-centered on authentic assignments that arouse student curiosity. Authentic tasks in the form of solving real problems that are relevant to student life; (2) students are involved in exploring and investigating; (3) learning is interdisciplinary; (3) knowledge is closely related to the world outside the classroom walls; (4) students work on complex assignments that involve high-level thinking skills, such as analyzing, synthesizing, designing, processing and evaluating information; (5) students produce products that can be shared with audiences outside the classroom; (6) learning is active and driven by students themselves, while lecturers, parents, and resource persons are helpful or directing; (7) the lecturer implements scaffolding, which is to provide assistance as needed and let students work freely when they are able to do it themselves; (8) students have the opportunity to engage in discourse in society; (9) students work with many sources; and (1) students often work together and have ample opportunities to discuss in order to solve problems (Barker, 1994; Gulikers, 2005).

\section{Designing Authentic Learning in Islamic Higher Education}

To be applied in Islamic higher education institutions, conceptually, authentic learning is practiced with the following design steps. (1) student orientation towards genuine problems; (2) organizing students to study; (3) guiding individual/group investigations; (4) develops and presents the work; (5) the lecturer prepares/prepares a scenario to be displayed; (6) appointing several students to study the scenario two days or several days before the teaching and learning activities to prepare the roles contained in the scenario; 
(7) lecturers form student groups with five members or according to needs; (8) provides an explanation of the competencies to be achieved in the material; (9) summoning students who have been appointed to play the scenario prepared beforehand; (10) each student sits in his group, each watching while observing the scenario being demonstrated; (11) after they are staged, each student is given a paper as a worksheet to discuss the scenario. For example, assessing the role played, looking for weaknesses and strengths of the role or the plot of the story; (12) each group presents their results and conclusions; (13) lecturers give general conclusions or evaluate all activities; (14) evaluation/reflection; and (15) closing. This design is essential to be tried by lecturers in Islamic higher education institutions because educational activities in these institutions tend to be based on textbooks, which were published several years ago. As a result, students are less connected to the real phenomenon of society. Students are only fed with ancient textbooks. Students are weak in understanding and responding to the dynamics of the development of Islamic culture, both at national and international levels (Husni, 2019b; Husni, Setiawan, Azis, Tantowie, \& Rizal, 2020; Husni \& Tantowie, 2017).

Another design that can be used to apply authentic learning in Islamic higher education are (1) formulating the problem, namely, the student's step in determining the problem to be solved; (2) analyzing the problem, i.e., the levels of the students to critically examine the issue from various points of view; (3) formulating hypotheses, i.e., steps of students to develop multiple possible solutions in accordance with their knowledge; (4) collecting data, namely the steps students look for and describe the information needed for problemsolving; (5) hypothesis testing, i.e., steps students take or formulate conclusions in accordance with the acceptance and rejection of the proposed hypothesis; and (6) formulating problem-solving recommendations; namely, the student steps describing recommendations that can be made according to the results of the hypothesis testing and the conclusion formulation.

Authentic learning in Islamic higher education institutions can also use the following design. (1) student orientation to the problem. At this stage, the Lecturer activities explain the learning objectives, define the logistics needed, propose phenomena or demonstrations, or stories to bring up questions, motivate students to be involved in solving the problems they choose. (2) organizing students to study. At this stage, the lecturer helps students define and organize learning tasks related to the problem. (3) guiding individual and group investigations. At this stage, the lecturer encourages students to gather appropriate information, carry out experiments, to get explanations, and solve problems. (4) develop and present the work. At this stage, the lecturer helps students in planning and preparing appropriate work such as reports, videos, 
and models and helps them to share assignments with their friends. (5) analyze and evaluate the problem-solving process. At this stage, the lecturer allows students to reflect or assess their investigation and the processes they use.

Lecturers who design authentic learning in Islamic higher education need to pay attention to several essential components of authentic learning if it is applied in Islamic higher education institutions. These components are (1) real-world relevance. Lecturers in Islamic higher education institutions need to develop authentic activities that are made as close as possible in accordance with professional assignments in the real world. Learning increases towards reality by asking students to work actively with abstract concepts, learn facts, and then study the social-cultural conditions of various disciplines. (2) illdefined problem. Challenges must not be made to be easily solved. Authentic learning activities relatively consist of complex tasks that must be completed and are open to some interpretation, which asks students to identify their own sub-tasks to be able to do the main task. (3) sustained investigation. Problems cannot be solved in minutes or hours. In contrast, authentic activities consist of complex problems that must be investigated by students in a continuous period of time. The problems that exist in authentic learning activities require a level of thought and an ongoing allocation of time. (4) multiple sources and perspectives. In authentic learning activities, students are not given a list of learning resources. Authentic learning activities provide opportunities for students to look for theoretical references, practical perspectives, from various sources, and train students to be able to distinguish which information is relevant and vice versa. (5) collaboration. The level of success is not only judged by individual student performance. Authentic learning activities make integral collaboration between learning in the classroom and its practice in the real world. (6) reflection (metacognition). Authentic learning activities allow students to choose and reflect on the material being studied, either individually or in groups. (7) interdisciplinary perspective. Relevance is not limited to only one domain or subject. instead, authentic learning activities have consequences for extending learning beyond certain disciplines, encouraging students to adopt diverse roles from various disciplines. (8) integrated assessment. In authentic learning activities, assessment is not only limited to summative assessment, but the main task of assessment is to be able to reflect the assessment process in the real world. (9) polished product. The conclusion is not only in the form of practice and sequence of preparation to make something. Authentic activities lead to the creation of an overall product that has value in it. (10) multiple interpretations and outcomes. Instead of producing one correct answer, obtained from the application of principles and 
procedures, authentic learning activities allow a variety of interpretations and solutions.

Some examples of the application of authentic learning activities are (1) simulation-based learning. E-learning is an online learning environment that uses simulation and role-playing to engage students in complex authentic decision making, develop communication, and the leadership skills needed to become successful practitioners in their fields. (2) peer-based evaluation. Calibrated Peer Review (CPR) is a free web-based program that allows lecturers/instructors to incorporate writing assignments into their applications, regardless of class size, and without increasing their assessment burden. Students are trained to be competent reviewers, then given the responsibility to get feedback from their friends. CPR manages the overall peer review, including the creation of assignments, electronic paper submissions, student training in reviewing, input analysis, and final preparatory performance reports. (3) work with remote instruments. Through the interface of an educational institution's website, it allows students around the world to experiment with devices located on the campus of an educational institution. Software agents oversee the use of instruments, setting priorities for individual experiments. With these instruments, students can access expensive equipment or rare instruments, which may not be obtained through classroom learning. The value of authentic learning is not limited to learning in life in real locations and practices, but authentic learning can be realized through careful design in webbased learning environments. Today, the web-based environment provides students with access to a variety of professional resources. Lecturers can use web-based communication tools to help students collaborate with one another, share, and build knowledge.

Technologies support for authentic learning environments in the Islamic higher education are (1) high-speed internet connectivity for the investigation of multimedia information, including dynamic data and the practice of visualizing complex phenomena and accessing relationships with expert advice. (2) synchronous and asynchronous communication and social networking tools to support teamwork. (3) intelligent guidance systems, virtual laboratories, and feedback mechanisms to capture student performance information and help them learn to transfer new situations. (4) mobile devices to access and enter data during field-based investigations.

There are several factors that support the creation of authentic learning to be effective learning in Islamic higher education. These factors are (1) learners in Islamic higher education look for connections. Assimilating new knowledge into the schemata structure of knowledge that students already have. (2) long-lived attachments come with practice. The concept needs to be 
"aired" repeatedly on a regular basis, associated with new information so that the concepts formed are not lost. (3) new contexts need to be explored. The concepts learned are always a more significant part of "learning activities" that are directly related to students' minds with the setting, activities, and social environment.

This learning can be used for students at all grade levels in Islamic higher education institutions. This learning can also be applied to students with various levels of ability. The principles of authentic learning are studentcentered; students learn actively and use authentic assignments. If this learning model is applied in an Islamic higher education institution, the learning process and results are believed to be increasingly quality. Why? Because authentic learning is a practical approach to teaching higher-order thinking processes, whereas Islamic higher education institutions have much to do with higher-order thinking skills. This learning will help students in Islamic higher education institutions to process information that has already become in their minds and compile their own knowledge about the social world and its surroundings. This learning is relevant for developing simple and complex basic knowledge. In this learning, lecturers in Islamic higher education institutions can play a role in raising problems or questions, encourage, motivate, provide teaching materials and facilities needed. In addition, lecturers at Islamic higher education institutions can provide scaffolding in the form of support to improve student inquiry and intellectual development abilities.

\section{Conclusion}

In the process of study habits in Islamic higher education, which more emphasis on reading, understanding, and textbooks analysis, lecturers at this institution need to propose and develop authentic learning models. Through authentic learning, students are invited to construct knowledge more relevant to their lives through careful investigation. Through this learning model, students are encouraged to explore, discuss, and build meaningful concepts and relationships in contexts that involve real problems that are more relevant to them. This learning model can be a measure of relevance or compatibility of the curriculum with the world that students will enter after graduation. Several design steps can be used by lecturers in Islamic higher education to implement this authentic learning model. 


\section{REFERENCES}

Agostinho, S. (2006). Using Characters in Online Simulated Environments to Guide Authentic Tasks. In Authentic Learning Environments in Higher Education. Hershey PA: Information Science Publishing.

Andersson, S. B., \& Andersson, I. (2005). Authentic Learning in a Sociocultural Framework: A Case Study on Non-formal Learning. Scandinavian Journal of Educational Research, 49(4), 419-436.

Banas, J. R. (2014). Impact of Authentic Learning Exercises on Preservice Teachers' Self-Efficacy to Perform Bullying Prevention Tasks. American Journal of Health Education, 45(2), 239-248.

Barker, P. (1994). Designing Interactive Learning. In Design and Production of Multimedia and Simulation-based Learning Material (pp. 1-30). https://doi.org/10.1007/978-94-011-0942-0_1

Cooper, D. E. (2011). Authenticity and Learning. New York: Routledge.

Donovan, M. S., Bransford, J. D., \& Pellegrino, J. W. (1999). How People Learn: Bridging Research and Practice. Washington, DC: National Academy Press.

Duis, M. (1995). Making Time for Authentic Teaching and Learning. Gateways to Experience. Kappa Delta Pi Record, 30(3), 136-138.

Gulikers, J. T. M. (2005). The Surplus Value of an Authentic Learning Environment. Computers in Human Behavior, 21(4), 509-521.

Herrington, A., \& Herrington, J. (2006). What is an Authentic Learning Environment? In A. Herrington \& J. Herrington (Eds.), Authentic Learning Environments in Higher Education. Hershey PA: Information Science Publishing.

Herrington, J. (2010). A Guide to Authentic e-Learning. New York: Routledge. Herrington, J., \& Parker, J. (2013). Emerging Technologies as Cognitive. British Journal of Educational Technology, 44(4), 607-615.

Herrington, J., Reeves, T. C., \& Oliver, R. (2014). Authentic Learning Environments. In Handbook of Research on Educational Communications and Technology (pp. 401-412). https://doi.org/10.1007/978-1-46143185-5_32

Hillis, P. (2008). Authentic Learning and Multimedia in History Education. Learning, Media and Technology, 33(2), 87-99.

Husni. (2016). The Challenges of Religious Education in Indonesia and the Future Perspectives. Religious Studies: An International Journal, 4(2). Retrieved from https://fssh-journal.org/index.php/jrs/article/view/12

Husni. (2019a). Konsep Ihsân dalam Wacana Pendidikan Islam. TAJDID, 26(1), 1-12. https://doi.org/10.36667/tajdid.v26i1.317 
Husni. (2019b). Moderate Muslims' Views on Multicultural Education, Freedom of Expression, and Social Media Hate Speech: An Empirical Study in West Java Indonesia. Jurnal Penelitian Pendidikan Islam, 7(2), 199-224. https://doi.org/10.36667/jppi.v7i2.370

Husni, Setiawan, I., Azis, A., Tantowie, T. A. J., \& Rizal, S. S. (2020). Validity and reliability of multicultural competency instruments for islamic education teachers. International Journal of Scientific and Technology Research, 9(2).

Husni, \& Tantowie, T. A. J. (2017). Religion, Modernism and Postmodernism: Study on Jean Baudrillard's Philosophy. Religious Studies: An International Journal, 5(2). Retrieved from https://fsshjournal.org/index.php/jrs/article/view/23

Jonassen, D. (1991). Objectivism vs. Constructivism. Educational Technology Research and Development, 39(3), 5-14.

Jonassen, D. (1994). Thinking Technology. Educational Technology Research and Development, 34(4), 34-37.

McKenzie, A. D., Morgan, C. K., Cochrane, K. W., Watson, G. K., \& Roberts, D. W. (2002). Authentic Learning: What is It, and What are the Ideal Curriculum Conditions to Cultivate It in? HERDSA 2002 Conference, 426-433.

Mishan, F. (2005). Designing Authenticity into Language Learning Materials. Bristol: Intellect Ltd.

Murphy, P. (2006). The Impact of Authentic Learning on Students' Engagement with Physics. The Curriculum Journal, 17(3), 229 - 246.

Parisi, L., \& Crosby, B. (2012). Making Connections with Blogging Authentic Learning for Today's Classrooms. Washington, DC: International Society for Technology in Education.

Robertson, M. (2014). Is This for Real? Authentic Learning for the Challenging Events Environment. Journal of Teaching in Travel \& Tourism, 12(2), 225-241.

Schumacher, A., \& Reiners, C. S. (2013). Designing Authentic Learning Environments in Chemistry Lessons: Paving the Way in Pre-Service Teacher Education. Sci \& Educ, 22(10), 2173-2191.

Slepkov, H. (2008). Teacher Professional Growth in an Authentic Learning Environment. Journal of Research on Technology in Education, 41(1).

Wilson, B., \& Cole, P. (1991). A Review of Cognitive Teaching Models. Educational Technology Research and Development, 39(4), 47-64. 
